\title{
Kemampuan Tanah Liat dengan Campuran Serbuk Gergaji sebagai Penahan Lindi di Tempat Pengolahan Akhir Sampah
}

\author{
Mochamad Arief Budihardjo
}

\author{
Departemen Teknik Lingkungan, Fakultas Teknik, Universitas Diponegoro, JI. Prof. Soedarto, \\ $\mathrm{SH}$, Kampus Undip Tembalang, Semarang, Indonesia 50275 \\ e-mail:m.budihardjo@ft.undip.ac.id
}

\begin{abstract}
Abstrak
Tempat Pengolahan Akhir (TPA) Sampah dengan sistem lahan urug harus dilengkapi dengan lapisan semi kedap (liner) yang berfungsi sebagai penahan lindi agar tidak mencemari lingkungan sekitar TPA. Di Indonesia, TPA banyak menggunakan lapisan tanah liat yang dipadatkan sebagai liner. Salah satu jenis tanah liat yang digunakan sebagai liner adalah bentonit. Bentonit memiliki permeabilitas rendah sehingga dapat menahan lindi dengan baik. Namun bentonit juga memiliki nilai batas-batas atterberg yang cukup tinggi sehingga mudah mengembang dan menyusut yang dapat memicu terjadinya retakan yang berpotensi mengurangi kemampuan liner dalam menahan lindi. Pada penelitian ini, serbuk gergaji yang memiliki sifat menahan air di tambahkan sebagai campuran tanah liat dengan tujuan untuk melihat pengaruhnya terhadap karakteristik dari bentonit. Pengujian batas-batas atterberg seperti batas cair, batas plastis, pengembangan bebas dan permeabilitas dari bentonit dengan penambahan serbuk gergaji dilakukan untuk mengetahui pengaruh serbuk gergaji terhadap perilaku bentonit. Penambahan serbuk gergaji yang diuji pada studi ini adalah sebesar 2\%, 3\% dan 5\% dari total berat kering. Hasil percobaan menunjukkan bahwa penambahan serbuk gergaji menurunkan batas cair, batas plastis dan pembengkakan bebas dari bentonit. Disisi lain, penambahan serbuk gergaji meningkatkan permeabilitas bentonit dari semula sebesar 1,24 $x$ 10-11 m/detik menjadi 3,98 × 10-10 m/detik dengan penambahan serbuk gergaji sebesar $8 \%$.
\end{abstract}

Kata kunci: bentonit; serbuk gergaji; permeabilitas

\begin{abstract}
Municipal solid waste landfill must be equipped with semi-permeable liner that function as leachate barriers. In Indonesia, the most prefered materials for liners is compacted clay. One of natural clay that can be employed as liner is bentonite. Bentonite has very low permeability and can be function as leachate impediments. However, bentonite has quite high of atterbeg limit properties that indicates its potential for swell and shrinkage. This characteristic of bentonite may trigger cracking that can reduce hydraulic performance of the bentonite. In this study, sawdust that has abilities to retain water was added as additional mixture of bentonite. Any alterations on the characteristic of the bentonite mixtures were eexamined. A series of atterberg limit test such as liquid limit, plastic limit and free swell were performed along with permeability testing. The amount of sawdust added were $2 \%, 3 \%$ and $5 \%$ from total dry weight. The result shows that sawdust adding may reduce the value of liquid limit, plastic limit and free swell index of the mixture. On the otherhand, the addition of sawdust can increases permeability of the mixtures. Pure bentonite has permeability of $1.24 \times 10-11 \mathrm{~m} / \mathrm{sec}$ while bentonite with $8 \%$ of sawdust has permeability of $3.98 \times 10-10 \mathrm{~m} / \mathrm{sec}$.
\end{abstract}

Keywords: bentonite; sawdust; permeability

\begin{abstract}
Pendahuluan
Peningkatan jumlah penduduk akan secara langsung meningkatkan jumlah limbah padat yang harus dikelola oleh pemerintah. Hingga saat ini pengelolaan persampahan masih menjadi permasalahan penting bagi setiap kota (Manaf et al, (2009). Secara umum, sampah yang dikumpulkan oleh petugas sampah diangkut dan dikirim ke tempat pengolahan akhir (TPA). Sampah yang sebagian besar
\end{abstract}

terdiri dari sampah organik kemudian ditimbun di TPA dan mengalami proses dekomposisi (Zurbrügg et al., 2012).

Selama proses dekomposisi, sampah organik akan menghasilkan lindi. Produksi lindi terbanyak terutama terjadi pada saat musim hujan. Air hujan akan meresap disela-sela timbunan sampah dan membawa senyawa-senyawa organik dan anorganik termasuk logam berat dengan konsentrasi yang cukup tinggi (El-Fadel et 
al., 2002). Umumnya, masalah lingkungan yang terkait dengan penimbunan sampah kota di TPA adalah berupa pencemaran air tanah (Beaven et al., 2001). Untuk mengurangi dampak lingkungan dari lindi, TPA harus dilengkapi dengan lapisan penahan lindi (liner) untuk mencegah lindi meresap dan mencemari tanah dan air tanah di sekitarnya (Yesiller dan Shackelford, 2010). Lapisan penahan lindi adalah lapisan semi kedap air yang berfungsi mencegah lindi agar tidak keluar dari sistem TPA. Pengelola TPA umumnya menggunakan lapisan tanah semi kedap seperti lapisan tanah liat yang dipadatkan di dasar TPA untuk mencegah infiltrasi lindi (Ludwig et al., 2002),

Salah satu jenih tanah liat yang sering digunakan sebagai liner TPA adalah bentonit. Bentonit merupakan salah satu jenis tanah liat yang mempunyai permeabilitas sangat rendah sehingga dapat digunakan sebagai liner penahan lindi TPA (Roberts and Shimaoka, 2008). Bentonit akan mengembang apabila terkena air, namun akan menyusut apabila dalam kondisi kering sehingga mudah retak. Kondisi kembang-susut ini akan mempengaruhi kemampuan lapisan bentonit sebagai penahan lindi (Tripathy dan Rao, 2009). Salah satu cara untuk mengurangi pengembangan bentonit adalah dengan mencampur bentonit dengan material lain, diantaranya adalah serbuk gergaji.

Serbuk gergaji sering dimanfaatkan dalam pengolahan sampah. Serbuk gergaji dapat berfungsi sebagai bulking agent, yaitu bahan yang dapat digunakan untuk menjaga kelembaban terutama pada saat proses komposting sampah organik (lqbal et al., 2010). Selain itu serbuk gergaji juga berfungsi sebagai adsorben yang kuat untuk kontaminan logam berat (Shukla et al., 2016). Penggunaan serbuk gergaji tidak hanya ramah lingkungan, tapi juga dapat mengurangi timbulan limbah serbuk gergaji di lingkungan. Namun, pengaruh penambahan serbuk gergaji terhadap konduktivitas hidrolik dan karakteristik kembang-susut bentonit belum diketahui. Oleh sebab itu, studi ini bertujuan untuk mengetahui perubahan perilaku kembangsusut dan konduktivitas hidraulik bentonit setelah ditambah serbuk gergaji.

\section{Metodologi Penelitian}

Tanah liat bentonit didapatkan dari pemasok lokal di Jawa Timur dengan berat jenis (specific gravity) 2,75, kadar air optimum (Optimum Moisture Content) sebesar $43 \%$ dan kandungan smectite sebesar $>75 \%$ (Tabel 1$)$.

Tabel 1. Komposisi kimia bentonit

\begin{tabular}{ll}
\hline Komponen & Proporsi \\
\hline Smectite & $>75 \%$ \\
Kuarsa & $<16 \%$ \\
Kaolin & $<9 \%$ \\
\hline
\end{tabular}

Sedangkan serbuk gergaji kayu yang digunakan berasal dari usaha pemotongan kayu lokal dengan jenis kayu yang bervariasi namun didominasi dengan kayu Kalimantan. Serbuk gergaji memiliki berat jenis sebesar 2,15 dengan optimum moisture content (OMC) sebesar 19,7\% (Tabel 2).

Tabel 2. Karakteristik serbuk gergaji

\begin{tabular}{lc}
\hline Properti & Nilai \\
\hline Optimum moisture & 19.6 \\
Content (OMC) & 1.45 \\
Maximum dry density & 2.15 \\
Specific Gravity & \multicolumn{1}{c}{ Persiapan bahan } \\
\hline \multicolumn{1}{c}{ dilakukan dengan }
\end{tabular}
menimbang bentonit dan serbuk kayu sesuai dengan variasi campuran yang diinginkan. Empat macam sampel disiapkan untuk eksperimen ini yaitu sampel bentonit tanpa penambahan serbuk kayu $\left(B_{1}\right)$, bentonit dengan penambahan sebuk kayu sebesar 2\% $\left(B_{2}\right)$, bentonit dengan campuran serbuk kayu 5\% $\left(B_{5}\right)$ dan bentonit dengan penambahan serbuk kayu $8 \%\left(B_{8}\right)$. Semua variasi bahan dicampur secara homogen dalam kondisi kering.

Batas plastis diukur dengan mengikuti prosedur dari ASTM D 4318-98 (ASTM, 2000). Pengujian ini dilakukan dengan menambahkan sedikit air pada sampel tanah lalu sampel digulung dengan telapak tangan hingga mencapai diameter sekitar 3 $\mathrm{mm}$. Prosedur diulang dengan variasi penambahan air hingga didapatkan campuran tanah yang pecah pada saat gulungan tanah mencapai diameter $3 \mathrm{~mm}$. Sampel tanah tersebut kemudian ditimbang dan ditempatkan di oven pengeringan untuk mendapatkan kadar air sampel, yang merupakan angka batas plastis (PL).

Uji batas cair dilakukan dengan menggunakan metode fall cone mengikuti AS 1289.3.9.1-2002 (Standards Australia, (2002). Tes ini dilakukan dengan menggunakan kerucut penetrometer dan sampel tanah yang dicampur dengan air suling. Sekitar 250 gram sampel digunakan dalam pengujian. Sampel kemudian 
dimasukkan ke dalam kontainer di bawah kerucut penetrometer. Dalam metode ini, kerucut baja yang memiliki kemiringan sudut $30^{\circ}$ dan berat $80 \mathrm{gr}$ dijatuhkan bebas. Perhitungan penurunan dimulai pada titik di mana kerucut menyentuh sampel dan menembus sampel selama 5 detik serta alat pengukur penurunan terbaca. Batas cair sampel ditentukan menurut kadar air sampel pada penetrasi sedalam $20 \mathrm{~mm}$ kerucut.

Indeks plastisitas ditentukan dengan berdasarkan ASTM D 4318-98 setelah batas cair dan batas plastis telah diperoleh (ASTM, 2000). Indeks plastisitas (PI) dihitung sebagai berikut:

$\mathrm{PI}=\mathrm{LL}-\mathrm{PL}$

Dimana indeks plastisitas dinyatakan dengan 'Pl', batas cair dengan 'LL' dan batas plastis dengan 'PL'.

Uji pengembangan bebas dilakukan dengan mengikuti IS 2720-40 (Indian Standards, 1977). Pengujian dilakukan dengan menggunakan sampel masingmasing sebanyak 2 gr dan silinder/gelas ukur. Dua gelas ukur disiapkan untuk masing-masing jenis sampel. Dua gram sampel dimasukkan ke dalam masingmasing silinder. Silinder pertama kemudian diisi dengan $100 \mathrm{ml}$ air suling dan silinder kedua diisi minyak tanah dengan volume sama yaitu $100 \mathrm{ml}$. Semua sampel kemudian didiamkan mengembang selama 24 jam. Volume akhir setiap silinder kemudian dicatat dan dihitung untuk mendapatkan indeks pengembangan.

Uji permeabilitas dilakukan dengan mengikuti metode falling head dari AS 1289.6.7.2-2001 (Standards Australia, 2001). Uji permeabilitas falling head dilakukan dengan mengalirkan air melalui sampel tanah yang terhubung ke pipa tegak yang berisi air. Pipa tegak tersebut dilengkapi dengan satuan tinggi sehingga banyaknya air yang mengalir melalui sample dapat dihitung. Sebelum dilakukan pengukuran, sampel tanah dijenuhkan terlebih dahulu dan pipa tegak diisi dengan air hingga ketinggian tertentu. Pengujian dimulai dengan mengalirkan air melalui sampel tanah hingga ketinggian air di pipa tegak turun. Pengujian ini dilakukan beberapa kali untuk mendapatkan nilai ratarata.

\section{Hasil dan Pembahasan}

Uji batas-batas Atterberg (batas plastis dan batas cair) dan uji free swell dilakukan sebelum pengujian kinerja hidrolik (permeability test). Uji batas plastis dilakukan dengan cara menggulung sampel tanah menggunakan tangan kosong untuk membentuk gulungan kecil yang pecah bila mencapai diameter sekitar $3 \mathrm{~mm}$. Batas plastik sampel $\mathrm{B}_{1}, \mathrm{~B}_{2}, \mathrm{~B}_{5}$ dan $\mathrm{B}_{8}$ adalah $55 \%, 51 \%$, 50\% dan 48\% (Tabel 3).

Batas cair sampel ditentukan dengan menggunakan pengujian penetrasi kerucut. Hasil pengujian diperoleh batas cair untuk masing-masing sampel adalah sebagai berikut: sampel $\mathrm{B}_{1}$ memiliki batas cair sebesar $530 \%$, sample $B_{2} 514 \%$, sample $B_{5}$ $496 \%$ dan sample $B_{8} 485 \%$ (Table 3 ).

Tabel 3. Batas-batas Atterberg

\begin{tabular}{ccccc}
\hline Sampel & $\begin{array}{c}\text { PL } \\
(\%)\end{array}$ & $\begin{array}{c}\text { LL } \\
(\%)\end{array}$ & PI & SI \\
\hline B1 & 55 & 530 & 475 & 44 \\
B2 & 51 & 514 & 463 & 43 \\
B5 & 50 & 496 & 446 & 41 \\
B8 & 48 & 485 & 437 & 40 \\
\hline
\end{tabular}

PL: Batas plastis

LL: Batas cair

PI: Indeks plastisitas

SI: Indeks pembengkakan bebas

Uji selanjutnya adalah uji uji pengembangan bebas atau free swell test mengikuti prosedur dari IS 2720-40 (Indian Standards, 1977). Sampel yang akan diuji dikeringkan dalam oven, dihaluskan dan disaring dengan saringan $425 \mathrm{~m}$. Dua silinder/gelas ukur 100ml disiapkan untuk masing masing jenis sampel. Untuk pengujiannya, $10 \mathrm{gr}$ sampel dimasukkan ke dalam setiap gelas ukur. Untuk tiap jenis sampel, satu gelas ukur diisi dengan air suling sedangkan gelas ukur kedua diisi dengan minyak tanah. Campuran/suspensi ini kemudian diaduk dengan batang pengaduk untuk menghilangkan udara yang terperangkap di dalam sampel dan kemudian didiamkan selama 24 jam. Volume akhir dicatat dan indeks pengembangan bebas dihitung dengan menggunakan persamaan berikut:

$$
\mathrm{SI}=\frac{\mathrm{V}_{\mathbb{d}}-\mathrm{V}_{\mathrm{K}}}{\mathrm{V}_{\mathrm{K}}} \times 100 \%
$$

Dimana; SI adalah indeks pengembangan bebas, Vd adalah volume sampel dengan air suling dan Vk adalah volume sampel dengan minyak tanah.

Hasil uji pembengkakan bebas dirangkum pada Tabel 3. Sampel $B_{1}$ yang mengandung bentonit tanpa tambahan campuran memiliki indeks pembengkakan bebas yang terbesar dibandingkan dengan 
bentonit dengan penambahan serbuk gergaji yaitu sebesar 44 . Sampel $B_{2}$ yang terdiri merupakan bentonit dengan penambahan $2 \%$ serbuk gergaji kayu memiliki indeks pembengkakan bebas sebesar 43 , sedangkan sampel $B_{5}$ dan $B_{8}$ memiliki indeks pembengkakkan bebas masing-masing sebesar 41 dan 40 . Indeks pengembangan bebas merupakan indikator awal kualitas tanah lempung yang dapat digunakan sebagai lapisan semi kedap TPA meskipun korelasi dengan kinerja hidrolik/permeabilitas belum terbentuk.

Uji selanjutnya adalah uji permeabilitas sampel. Uji ini sangat diperlukan sebagai syarat utama apakah suatu bahan memiliki kemampuan untuk menahan rembesan lindi TPA. Pengujian permeabilitas ini dilakukan dengan menggunakan metode falling head dengan mengacu standar AS 1289.6.7.22001 (Standards Australia, 2001). Hasil uji permeabilitas menunjukkan adanya perubahan kemampuan hidrolik bentonit setelah dicampur dengan serbuk gergaji. Koefisien permeabilitas terendah ditunjukkan oleh sampel yang mengandung bentonit murni tanpa penambahan serbuk gergaji $\left(B_{1}\right)$ dengan nilai sebesar $1,24 \times 10$ ${ }_{11} \mathrm{~m} /$ detik. Sedangkan penambahan serbuk gergaji sebesar $2 \% \quad\left(B_{2}\right)$ meningkatkan koefisien permeabilitas menjadi 3,98 $\times 10^{-10}$ $\mathrm{m} /$ detik. Sedangkan nilai permeabilitas sampel $B_{5}$ dan $B_{8}$ adalah $4,36 \times 10^{-10}$ $\mathrm{m} /$ detik dan $5,42 \times 10^{-10} \mathrm{~m} /$ detik. Semakin banyak serbuk gergaji yang ditambahkan pada bentonit, koefisien permeabilitas sample akan meningkat. Hasil ini sesuai dengan penelitian sebelumnya bahwa penambahan serbuk gergaji sebagai campuran tanah akan meningkatkan permeabilitas tanah (Eusufzai et al, 2007)

Berdasarkan nilai permeabilitas maksimal material liner TPA yang direkomendasikan yaitu $>10^{-8} \mathrm{~m} /$ detik, maka semua sampel bentonit dengan penambahan serbuk gergaji masih memenuhi syarat untuk digunakan sebagai liner TPA karena memiliki koefisien permeabilitas dibawah $10^{-8} \mathrm{~m} /$ detik.

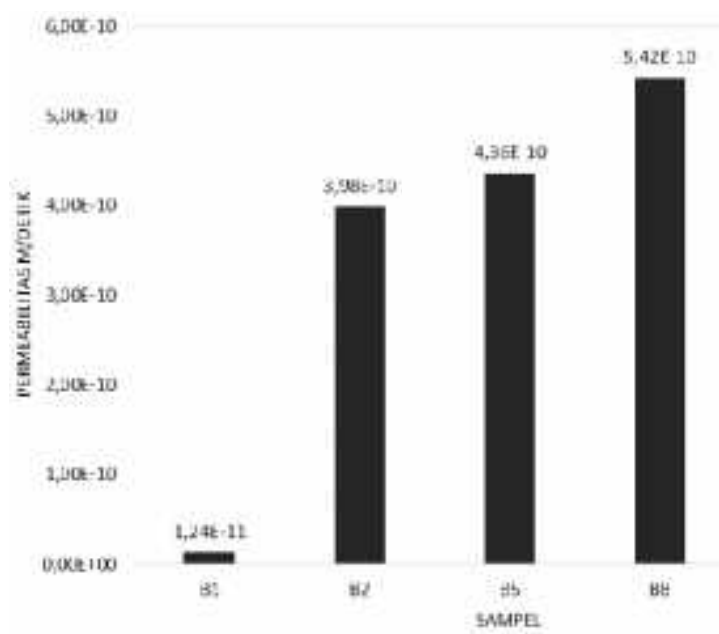

Gambar 1. Permeabilitas tiap sampel

\section{Kesimpulan}

Studi ini meneliti pengaruh penambahan serbuk gergaji terhadap batas- batas atterberg dan konduktivitas hidrolik bentonit dengan peruntukan sebagai liner TPA. Campuran serbuk gergaji yang ditambahkan pada studi ini adalah sebesar $2 \%, 5 \%$ dan $8 \%$. Hasil penelitian menunjukkan bahwa penambahan serbuk gergaji menurunkan batas cair, batas plastis dan mengurangi indeks pengembangan bebas bentonit. Namun, penambahan serbuk gergaji pada bentonit meningkatkan koefisien permeabilitas dari bentonit. Bentonit tanpa campuran serbuk gergaji memiliki koefisien permeabilitas sebesar $1,24 \times 10^{-11} \mathrm{~m} /$ detik sedangkan koefisien permeabilitas tertinggi sebesar $5,42 \times 10^{-10} \mathrm{~m} /$ detik ditunjukkan oleh bentonit dengan campuran serbuk gergaji sebesar $8 \%$.

\section{Daftar Pustaka}

ASTM (2000). D 4318-98: Standard test method for liquid limit, plastic limit and plasticity index of soils. Annual Book of ASTM Standards, West Conshohocken, Pennsylvania.

Beaven, R., Knox, K., Croft, B., (2001). Operation of leachate recirculation trial in a landfill test cell. In: Christensen, T.H., Cossu, R., Stegmann, R. (Eds.), Sardinia 2001, Eighth International Waste Management and Landfill Symposium, Cagliari Sardinia, pp. 595-604.

El-Fadel M, Bou-Zeid E, Chahine W, Alayli B. (2002). Temporal variation on leachate quality room pre-sorted and baled municipal solid waste with high organic and moisture content. Waste Manage (Oxford) 22:269-282

Eusufzai, M. K., Maeda, T., \& Fujii, K. (2007). Field evaluation of compost, 


\section{ISSN 2550-0023}

sawdust and rice straw biomass on soil physical and hydraulic properties. Japanese Journal of Society of Soil Science and Plant Nutrition, 107, 3-16.

Ludwig, Chr, Stefanie Hellweg, and Samuel Stucki. (2002). Municipal Solid Waste Management. Berlin and Heidelberg: Springer-Verlag.

Indian Standards (1977). IS 2720-40: Methods of Test for Soils - Part XI: Determination of Free Swell Index of Soils, New Dehli: Bureau of Indian Standards.

lqbal, M. K., Shafiq, T., \& Ahmed, K. (2010). Characterization of bulking agents and its effects on physical properties of compost. Bioresource Technology, 101(6), 1913-1919.

Manaf, L. A., Samah, M. A. A., \& Zukki, N. I. M. (2009). Municipal solid waste management in Malaysia: Practices and challenges. Waste management, 29 (11), 2902-2906.

Roberts, A. A., \& Shimaoka, T. (2008). Analytical study on the suitability of using bentonite coated gravel as a landfill liner material. Waste Management, 28(12), 2635-2644.

Standards Australia (2001). AS 1289.6.7.22001: Methods of Testing Soils for Engineering Purposes - Method 6.7.2: Soil Strength and Consolidation Tests - Determination of Permeability of a Soil - Falling Head Method for a Remoulded Specimen, New South Wales: SAIGlobal.

Standards Australia (2000). AS 1289.3.9.12002: Methods of Testing Soils for Engineering Purposes - Method 3.1.2: Soil Classification Tests Determination of the Cone Liquid Limit of a Soil, New South Wales: SAIGlobal.

Tripathy, S., \& Rao, K. S. S. (2009). Cyclic swell-shrink behaviour of a compacted expansive soil. Geotechnical and Geological Engineering, 27(1), 89-103.

Yesiller, N., and C. D. Shackelford. 2010. "Chapter 13: Geoenvironmental Engineering." In Geotechnical Engineering Handbook, Edited by: B. M. Das, Fort Lauderdale, United States: J.Ross Publishing.

Zurbrügg, C., Gfrerer, M., Ashadi, H., Brenner, W., \& Küper, D. (2012). Determinants of sustainability in solid waste management-The Gianyar Waste Recovery Project in Indonesia. Waste management, 32(11), 21262133. 